\title{
Az erkölcsi ítéletalkotás fejlődése és fejlesztési lehetőségei intézményes keretek között
}

\author{
Vincze Györgyi \\ ELTE Neveléstudományi Doktori Iskola, \\ ELTE Bárczi Gusztáv Gyógypedagógiai Kar, Gyógypedagógiai Pszichológiai Intézet
}

\begin{abstract}
Absztrakt
A tanulmány az erkölcsi ítéletalkotás fejlődésének és mérésének szakirodalmi öszszefoglalására tesz kísérletet. A téma gazdag filozófiai múlttal rendelkezik, melynek teljes feltárása jelen munkának nem volt célja, így csupán azoknak az elméleteknek a bemutatására szorítkoztam, amelyek hatással voltak a 20. század nagy pszichológiai irányzataira: a pszichoanalitikus iskolára, a szociális tanuláselméletre és a kognitív fejlődéselméletre. Az, ahogyan ma az erkölcsi ítéletalkotás fejlődéséről gondolkodunk, Jean Piaget (1965) és Lawrence Kohlberg (1976) klasszikus elméletein, vagy éppen ezek kritikáján alapul. Ezek bemutatása után térek ki az újabb kutatási irányokra, amelyek a ma forgalomban lévő, az erkölcsi fejlődés szintjének felmérésére alkalmas eszközöket adták, valamint jelentősen átírták azt, amit az erkölcsi gondolkodás megjelenésének kezdetéről korábban gondoltunk. Kitérek az erkölcsi ítéletalkotás szociális kompetenciába való integrálásának lehetőségére, mely hazánkban elterjedt nézőpont a széles körben alkalmazott DIFER-mérések miatt. Bemutatom, hogy milyen lehetőségek vannak az erkölcsi ítéletalkotás intézményes keretek közötti fejlesztésre, milyen a szakemberképzés, és milyen módszertani elgondolások jelennek meg.
\end{abstract}

Kulcsszavak: erkölcsi ítéletalkotás, klasszikus és új elméletek, mérési eszközök, intézményi szabályozás, módszertan

\section{Bevezetés}

„Senki sem jó véletlenül. Az erényt tanulni kell."

Seneca sorai óta évszázadok teltek el, de a 20. századi pszichológiai iskolák is hasonlóan vélekednek az erkölcsről: a morális viselkedés nem velünk született, hanem tanult magatartásforma. Az erkölcs a társadalom által

\footnotetext{
${ }^{1}$ Sárosi, Gy. (1943, ford.) Seneca leveleiből. Officina nyomda és kiadóvállalat. p. 119.
} 
szentesített szabályokból tevődik össze, amelyeknek legfontosabb területe a viselkedés szabályozása. Azt, hogy az erkölcs társadalmi termék; mi sem bizonyíthatja ezt jobban, mint hogy az erkölcs mindig az adott társadalommal együtt változik (Durkheim, 1917 idézi Piaget, 1969). Az erkölcs a jó és a rossz közti különbségtétel képessége és a cselekvő felelössége - ebben az értelemben pedig a világ müködésének feltétele (Heller, 1994).

Kérdés azonban, hogy mégis hogyan megy végbe az a folyamat, amelyet az erkölcsi ítéletalkotás fejlődésének nevezünk? Hogyan tanuljuk meg a számtalan kontextusfüggő viselkedési szabályt, mi alapján döntünk morális kérdésekben, honnan tudjuk valamiről, hogy igazságos vagy igazságtalan.

Az erkölcsi ítéletalkotással kapcsolatos teoretikus kérdések mellett a terület kutatása is sok kérdést vet fel, fóként egy technikai problémát, hogy hogyan tudjuk megfoghatóvá, mérhetővé tenni egy ember normáit, értékeit. $S$ még inkább kérdés: hogyan vizsgáljuk ezen értékek és normák változását (Szekszárdi et al., 2000).

$S$ ha képesek voltunk megvizsgálni ezt a nehezen megfogható területet, következhet az a kérdés, amely a gyakorlatban dolgozó szakemberek (például kisgyermeknevelők, óvodapedagógusok, tanítók, gyógypedagógusok, iskolapszichológusok, szociális munkások) érdeklődésére leginkább számot tarthat. Hogyan lehet az erkölcsi ítéletalkotás fejlődését kedvező irányba terelni? Ha az erényt tanulni kell, melyek azok a módszerek, amelyekkel ezt a folyamatot hatékonyan támogathatjuk? Milyen lehetőségei vannak egy pedagógusnak intézményes keretek között? A következőkben ezekre a kérdésekre keresem a válaszokat.

\section{Filozófiai gyökerek}

Az újszülöttek világrajövetele rendszeresen ismétlődő barbár invázió. Parsons (1954, idézi Ranschburg, 1998) ezzel arra utal, hogy a gyerekek kezdetben nem ismerik annak a társadalomnak a normáit, szabályait és értékrendszerét, amelybe beleszületnek, hanem később tanulják meg. E gondolat gyökere egészen Arisztotelészig nyúlik vissza, aki szerint az erkölcsi erények természettől fogva nincsenek meg bennünk, hanem a szokásból keletkeznek (Arisztotelész, 1987). Rousseau szintén amellett érvel, hogy erkölcsi ismereteinket a saját vagy mások tapasztalatából szerezzük (Rousseau, 1997).

Az erkölcs tárgyalásánál kikerülhetetlen a felelösség kérdésköre. Felelősség nélkül nincs erkölcs sem, hiszen elvesztené az értelmét. Arisztotelész (1987) azt mondja, hogy csak akkor vonhatunk bárkit is felelősségre a tetteiért, ha a saját akaratából cselekedett. Nincs helye dicséretnek vagy megrovásnak azért, ami kényszer vagy tudatlanság miatt megy végbe. Rousseau (1997) hasonló állásponton van: az ember csak az akarattal, szándékosan elkövetett hibákért vonható felelősségre, a tudatlanságból eredőekért nem. Ezzel a nézőponttal ellentétesnek tekinthető az „ignorantia juris non excusat" elve, ami a jelenkor jogalkotásában talán az egyik legismertebb. Ez azt 
mondja ki, hogy ha valaki nem ismeri a törvényt, az még nem mentesíti őt a felelősség alól. E nézetütközés egyfajta feloldását Kant (1991) kínálja. Az ő szemében az az ember morális, aki tud élni a választás szabadságával. Úgy véli, hogy a választás lehetősége még a legvégletesebb körülmények között is adott, és képesnek kell lennünk minden anyagi haszontól vagy más előnyöktől elvonatkoztatva dönteni.

Mi alapján mondunk azonban ítéletet egy cselekedet fölött? Vajon a szándék-e a fontosabb, vagy a következmény? Kant (1991) szerint ítéletünket a következmény alapján kell meghoznunk, a szándék elhanyagolható. Kifejezi azt az igényét, hogy kell egy szükségszerü, feltétlen erkölcsi törvény, amely minden esetben alkalmas az iránymutatásra: ez a kategorikus imperatívusz, ami maga az emberséges viselkedés. Abélard ezzel szemben amellett érvel, hogy csak a szándékot kell nézni egy tett megítélésekor, függetlenül attól, hogy végül milyen következményekkel szembesülünk. Ő a cselekedet előzményére koncentrál; tehát nézőpontját a szándéketika jellemzi. Számára a lelkiismeret, a belső indíték helyessége olyannyira fontos, hogy az eredménytől eltekint. A rossz szándékot bünnek tekinti akkor is, ha nem követi semmilyen tett (Bertók, 2013).

A következmény-és szándéketika perspektíváira rímel a gyermeki ítéletalkotás fejlődése. Jean Piaget (Piaget \& Inhelder, 2004) vizsgálatai során arra a következtetésre jutott, hogy minél fiatalabb egy gyerek, annál inkább az objektív felelősség irányába dönt, tehát a nagyobb kárral járó vétket minősíti nagyobb véteknek, tekintet nélkül a szándékra, majd az életkor növekedésével a gyerekek egyre inkább képesek az utóbbit is figyelembe venni.

A következőkben azt fogom bemutatni, hogy a 20. és 21. században hogyan változott az, amit az erkölcsi ítéletalkotás fejlődéséről gondolunk: a klasszikus irányzatoktól kezdve egészen napjainkig, és ez hogyan befolyásolta a kutatási irányokat.

\section{Klasszikus pszichológiai kutatások}

\section{Pszichoanalitikus iskola}

A pszichoanalitikus elmélet elválaszthatatlanul összefonódott Sigmund Freud nevével. Freud strukturális személyiségelmélete alapján a személyiségnek három összetevője van: az Ego (én), az Id (ösztön-én) és a Szuperego (felettes én). Az ösztön-én az örömelvnek megfelelően müködik, amely szerint a szükségleteknek azonnal ki kell elégülniük. Az objektív valósághoz való alkalmazkodásra az Ego szolgál, feladata, hogy az ösztön-én impulzusait a külvilág igényeinek figyelembevételével elégítse ki. A felettes én dönt arról, hogy mi helyes és helytelen, a szülői és társadalmi értékek alapján. Introjekciónak nevezzük azt a folyamatot, amely során a gyermek a szülők (és ezzel együtt a tágabb társadalom értékeit is) átveszi. A felettes én két alrendszere az énideál és a lelkiismeret. Az énideál tartalmazza a helyes, a szülők által 
elvárt viselkedések képzetét, míg a lelkiismeret a helytelenített és büntetett viselkedésekre vonatkozó tiltásokat. A büntudat a helytelen viselkedés következménye (Freud, 1991).

Az alapján, hogy a felettes én milyen mértékben épül be a személyiségbe, többféle típusú emberről beszélhetünk. Ha egyáltalán nem épül be, az azt jelenti, hogy olyan, mintha az illetőnek nem lenne lelkiismerete. Hiányzik az a személyiségrész, amely a vágyakat és kielégülési törekvéseket korlátok közé szorítaná. Az ilyen, amorálisként jellemezhető embert az antiszociális viselkedéstől csak a külső autoritás tarthatja vissza. Immorális az a személy, akinek az esetében az erkölcsös viselkedés nem belülröl fakad. Ha nincs jelen a külső kontrollt képviselő személy, nem képes ellenállni a csábításnak. És végül morális az az ember, aki akkor is erkölcsösen viselkedik, ha senki nem látja, azaz a viselkedése hátterében belső motiváció áll (Ranschburg, 1998).

\section{Szociális tanuláselmélet}

A pszichoanalitikus irányzat rámutatott arra, hogy az erkölcsi fejlődésben jelentős szerepet játszik, hogy milyen szülői példa van a gyerekek előtt. A szociális tanuláselméleti megközelítés szerint az erkölcsi szocializáció megerősítéseken keresztül alakul, amelyben központi szerepet játszik a viselkedés modellje, és hogy a megfigyelő tanúja-e annak, hogy megerősítik a modell viselkedését (Ranschburg, 1998).

Ha ennek nyomán a megfigyelő szert tesz arra a képességre, hogy megismételje a modell cselekvését, akkor megfigyeléses tanulásról beszélünk. Annak, hogy a megfigyeléses tanulás létrejöhessen, több feltétele van. Szükség van arra, hogy a megfigyelő kellően motivált legyen arra, hogy figyeljen a modell viselkedésére, képes legyen megőrizni az emlékezetében a tapasztaltakat, majd képes legyen az adott viselkedést reprodukálni (Bandura, 1986).

A pszichoanalitikus iskola álláspontjához képest a szociális tanuláselmélet tehát kimondja, hogy az erkölcsi ítéletalkotás fejlődéséhez nem elégséges, ha megfelelő modell áll a gyermek előtt. Szükség van arra is, hogy tanúja legyen annak, hogy a modell viselkedését pozitívan megerősítik, illetve az ő aktív, motivált közremüködésére az elvárt viselkedés reprodukciójában (Bandura, 1986).

\section{Kognitív fejlödéselmélet}

Míg a szociális tanuláselmélet a környezeti feltételekre helyezi a hangsúlyt, addig az erkölcsi szocializáció kognitív elmélete szerint az erkölcsiség kialakulása a gondolkodás fejlődésében gyökerezik (Piaget, 1965). Ezt a nézetet alátámasztják Kohlberg és Turiel vizsgálatai (1972), amelyek szerint az autonóm moralitás kialakulásához magas fokú intellektuális fejlettség szükséges (Mönks \& Knoers, 2004).

A normák és értékek internalizálásának folyamatáról alkotott nézetét tekintve a kognitív fejlődéselmélet álláspontja hasonlít a pszichoanalitikus 
iskoláéhoz, miszerint a normák és értékek az eszményképnek tartott személyekkel való identifikáció által válnak belsővé. Lutte hét európai országban vizsgálta az identifikáció folyamatát serdülőkorban. Vizsgálatából az derült ki, hogy a 12-16 évesek kezdetben a közvetlen környezetükből választanak maguknak ideált, majd az életkor előrehaladtával egyre távolabbi körökből, míg végül megjelennek az elvont eszményképek. Kohlberg szerint a morális fejlődést az identifikáció mellett az erkölcsi nevelés is elősegíti (Mönks \& Knoers, 2004).

Az erkölcsi fejlődés két, talán legjelentősebb elméletalkotója Jean Piaget és Lawrence Kohlberg. A fejlődés mindkettőjük szerint a relativizálódás felé halad, azaz minél inkább magasabb szinten áll valaki az erkölcsi fejlődésben, annál inkább képes figyelembe venni ítéletalkotáskor a szándékot, illetve a körülményeket. Mindkét elméletalkotó egyetért abban, hogy az erkölcs tanítható. Különbség, hogy Piaget szerint tízéves kor körül közel állunk az erkölcsi fejlődés csúcsához, Kohlberg ezzel szemben úgy gondolta, hogy ez a fejlődés körülbelül 16-17 éves korig tart (Piaget \& Inhelder, 2004; Kohlberg, 1976).

Piaget az erkölcsi fejlődés két szintjét különböztette meg. Az első szint a heteronómia, ami itt azt jelenti, hogy külsőleg megszabott, és a 7-8 évesnél kisebb gyerekekre jellemző. A jó és a rossz a felnőttek reagálásától függ; tehát a mérges szülő rossz gyereket jelent (Paley, 1981, idézi Cole \& Cole, 2003). Az utasítások hatalma összekapcsolódik annak fizikai jelenlétével, aki az utasításokat adta. Az ő távollétében a törvény érvényét veszti, és ha azt a gyerek megszegi, az csupán pillanatnyi rossz érzést eredményez (Piaget \& Inhelder, 2004). Ebben az életkorban hazudni, lopni nem önmagában erkölcstelen, hanem azért, mert ezzel a gyerek tilalmat szeg meg. Majd 7-8 éves kor után a gyerekek új erkölcsi relációkhoz jutnak el a társas együttmüködés fejlődésével, amelyek bizonyos autonómiához vezetnek (Piaget \& Inhelder, 2004). A nagyobbak a szabályokat megállapodás termékének tekintik, elfogadják, hogy módosíthatók, ha ebben mindannyian megegyeznek. Ebben az életkorban a szabályt már nem engedelmességből, hanem belátásból kell követni. Ez az autonómia szintje (Mérei \& Binét, 1981). Piaget az erkölcsi gondolkodás fejlődését három területen vizsgálta: a játékszabályok terén, az erkölcsi realizmus tekintetében (a viselkedés objektív és szubjektív értékelésének kapcsolatát vizsgálta), és az igazságról, a törvényről alkotott gyermeki elképzelések területén (Piaget, 1965).

Kohlberg (1976) a vizsgálatai során a gyerekeknek olyan történeteket mondott, amelyek erkölcsi dilemmákat tartalmaztak. Az erkölcsi dilemmák jellemzője, hogy egy etikai szempont ütközik valamilyen más, nem etikai szemponttal, például a törvényi szabályozással. Az erkölcsi dilemmákra nem létezik jó megoldás, és konszenzus sincs a megoldásukra. A történetekhez többféle megoldás tartozott, amelyekből azt kellett kiválasztani, amelyiket helyesnek tartották, és a választást meg is kellett indokolni. Kohlberg leghíresebb története a Heinz-dilemma: „Valahol Európában egy asszony rákban haldoklott. Egy gyógyszer, amelyet nem sokkal korábban fedezett fel egy 
ugyanabban a városban élő gyógyszerész, esetleg megmenthette volna az életét. A gyógyszerész 2000 dollárért árulta a szert, tízszer annyiért, amenynyibe az előállítása került. A beteg asszony férje, Heinz mindenkit felkeresett, akit csak ismert, hogy pénzt kérjen kölcsön, de az orvosság árának csak a felét tudta összegyüjteni. Megmondta a gyógyszerésznek, hogy a felesége haldoklik, és arra kérte, adja olcsóbban az orvosságot, vagy tegye lehetővé, hogy később fizesse ki az árát. A gyógyszerész azonban nemet mondott. A férj elkeseredésében betört a gyógyszerész üzletébe, hogy ellopja az orvosságot a feleségének. Szabad volt-e ezt tennie? Miért?" (Cole \& Cole, 2004, p. 564-566).

Piaget elméletéből kiindulva Kohlberg 3 szint és 6 szakasz megkülönböztetését javasolta, amelyek alapján az erkölcsi fejlődés a fiatal felnőttkorig tart. (1. táblázat) A prekonvencionális szintet az jellemzi, hogy a gyerekek gondolkodása nem társadalmi konvenciókra, illetve törvényekre támaszkodik. Még nem veszik figyelembe, hogy a társadalmi együttéléshez közös viselkedési normákra van szükség. A konvencionális szinten már képesek figyelembe venni a társadalmi konvenciókat. A posztkonvencionális szinten pedig már a társadalmi konvenciókon túli szempontok figyelembevételére is képesek. Felismerik azt, hogy a törvények gyakran ellentmondásba kerülnek morális elvekkel. Sokan csak később, vagy egyáltalán nem érik el ezt a szintet (Kohlberg, 1976). Kohlberg leírt egy úngynevezett nulla-állapotot is, amely a prekonvencionális szint előtt figyelhető meg. Ekkor a gyermek azt tartja jónak, ami összhangban van a kívánságaival és szükségleteivel. 1981-ben Erikson nyolc fejlődési szakaszának hatására kiegészítette szakaszolását a 7. szakaszszal, amelyben az ember a kötelesség határain túlmenő, egy magasabb rendü hatalom által irányított cselekvésre érez késztetést. Ezen a szinten nyilvánvaló a vallásossággal való összefüggés (Mönks \& Knoers, 2004).

1. táblázat

Az erkölcsi fejlődés szintjei és szakaszai Kohlberg (1976) alapján

\begin{tabular}{|c|c|}
\hline \multirow{2}{*}{$\begin{array}{l}\text { I. Prekonvencionális } \\
\text { szint }\end{array}$} & 1. szakasz: Heteronóm erkölcs \\
\hline & 2. szakasz: Individualizmus, instrumentális erkölcs, csereelv \\
\hline \multirow{2}{*}{$\begin{array}{l}\text { 2. Konvencionális } \\
\text { szint }\end{array}$} & $\begin{array}{l}\text { 3. szakasz: Kölcsönös személyközi elvárások, viszonyok és személy- } \\
\text { közi igazodás }\end{array}$ \\
\hline & 4. szakasz: Társadalmi rendszer és lelkiismeret \\
\hline \multirow{2}{*}{$\begin{array}{l}\text { 3. Posztkonvencio- } \\
\text { nális szint }\end{array}$} & 5. szakasz: Társadalmi szerződés, hasznosság és egyéni jogok \\
\hline & 6. szakasz: Egyetemes etikai elvek \\
\hline
\end{tabular}




\section{Modern elméletek és kutatások - a legkisebbektől a felnőttekig}

Az erkölcsi ítéletalkotás kutatásában Piaget és Kohlberg kiemelkedő szerepe megkérdőjelezhetetlen, ugyanakkor a forgalomban lévő fejlődéslélektannal foglalkozó szakirodalom jelentős hiányossága, hogy e klasszikus elméletalkotókat ért kritikákat és az újabb kutatási irányokat, ha meg is említi, nem tárgyalja részletesen (Vajda, 1999). A következőkben ennek a hiányosságnak a pótlására teszek kísérletet.

Piaget és Kohlberg egyik legismertebb kritikusa Carol Gilligan (1982, idézi Vajda, 1999). Szerinte az erkölcs nem abszolút, hanem relatív fogalom, és amellett érvel, hogy a férfi és a női erkölcs alapvetően eltérő. Gilligan rávilágít a nők és a férfiak erkölcsi ítéleteinek minőségi különbségeire: a nők erkölcsi ítéleteit jellemzően a gondoskodás vágya és az empátia motiválja, míg a férfiak döntéseit általában a szabálykövető magatartás.

A kognitív fejlődéselméleti perspektíva alternatívájaként jelenik meg Turiel és Nucci (1978, idézi Vajda, 1999) nézőpontja, akik úgy gondolják, hogy a gyerekek nem tanulás útján, hanem spontán fejlődés során sajátítják el azt a képességet, hogy megkülönböztessék az erkölcsi szabályokat a szociális szabályoktól. Ezek megkülönböztetése azért jelentős, mert a szociális szabályok társadalmi konvenciókra épülnek; ide tartoznak például az illemszabályok is. Ezek kultúránként, de akár az adott szociális kontextus függvényében is változhatnak. Ezzel szemben szerintük az, amit morális viselkedésnek tartunk, objektívnek és univerzálisnak tekinthető. Feltételezték, hogy e két terület egymástól függetlenül fejlődik. Bár ezt a nézőpontot nagy elemszámú vizsgálatokkal igyekeztek igazolni, korai vizsgálataikkal kapcsolatban komoly módszertani kifogások vetődnek fel, például, hogy az alkalmazott történetekből, amelyeket a gyerekeknek el kellett bírálniuk, világosan látszik, hogy mi a vizsgálatvezető által elvárt „helyes” válasz.

Az Elliot Turiel nevéhez köthető kulturális pszichológiai irányzat szerint az egyének azonosulnak a saját kultúrájuk szociális és morális értékrendjével. Mivel jelentős különbségek vannak az individualista és a kollektivista kultúrák között, joggal feltételezhetjük, hogy ezeknek a jellemzői hatással lesznek a morális értékek milyenségére is. Egy individualista kultúrában, amely a választás szabadságára és a függetlenségre épül, a moralitás elsősorban a jogokon alapszik. Egy kollektivista kultúrában jelentősebb szerepet tölt be a csoport, és az egymástól való kölcsönös függés. A moralitás a kötelességekhez és szabályokhoz való ragaszkodáson alapul (Turiel \& Banas, 2020). A kulturális hatások jelentőségére a következőkben még visszatérünk.

Turiel (Turiel \& Banas, 2020) szerint a morális ítéletalkotást jelentősen befolyásolja az a társadalmi kontextus, amelyben döntenünk kell. Például az olyan játékok vagy sporttevékenységek esetében, amelyekben a résztvevők önként vonódnak be, és mindenki egyetért a szabályokkal, a morális szabályok felülíródhatnak. Egy kísérletben 6-11 éves gyerekek vélekedését vizsgálták a szóbeli bántalmazással kapcsolatban. A gyerekek nagy része elfo- 
gadhatónak találta, hogy valakit „hülyének” nevezzenek egy játék során, de csak abban az esetben, ha a játékszabályt mindenki elfogadta, önként vettek benne részt, és tudták, hogy ebben a játékban ez előfordulhat. A játék kontextusán kívül ugyanez a viselkedés nem volt számukra elfogadható.

Tehát az adott társadalmi kontextus jelentősen befolyásolja, hogy hogyan értékelünk egy helyzetet, de a legtöbbször úgy kell morális döntést hoznunk, hogy egynél több szempontot kell figyelembe vennünk. Gyakran különböző morális célok ütköznek egymással, vagy morális célok ütköznek társadalmi szempontokkal. Egy nagyon egyszerủ példával élve, lehet egy hazugság is morális szempontból helyes döntés, ha egy gyilkosnak hazudunk, aki afelől érdeklődik, merre ment a kiszemelt áldozata. Ebben az esetben az okozhatja a dilemmát, hogy mondjunk igazat, mert az a tisztességes, vagy mentsük meg egy ember életét (Turiel \& Banas, 2020). Befolyásló tényező az is, hogy milyen kapcsolatban vagyunk a másikkal. Serdülőket vizsgálva (Turiel \& Gingo, 2017, id. Turiel \& Banas, 2020) a túlnyomó többség elfogadhatóbbnak tartotta a szülők megtévesztését, mint a kortásaikét. A serdülők válaszai alapján a kortársakkal való kapcsolat az egyenlőségen és a kölcsönösségen alapul, amibe a hazugság semmiképpen sem fér bele, míg a szülővel való viszony aszimmetrikus, és gyakran az autoritásra épül.

Az erkölcsi ítéletalkotás fejlődését kutató klasszikus vizsgálatok esetében (Piaget, 1965; Kohlberg, 1976) azt látjuk, hogy 4-5 évesnél idősebb gyerekeket vontak be, tehát az ennél fiatalabb korosztály esetében nem voltak megfigyelések. Az újabb kutatások azonban igyekeztek kiterjeszteni a vizsgálatokat az ennél kisebb gyerekekre is, és azt láthatjuk, hogy jól megtervezett kísérletek segítségével már az első életévben megcsillan a morális ítéletalkotás és az etikai érzék szikrája. De hogyan lehet kisbabákat vizsgálni? Van valami, amit már az egészen kicsik is tudnak kontrollálni: ez pedig a szemmozgás. Ha valamit érdekesnek vagy meglepőnek találnak, azt hosszabb ideig nézik. A babák nézésének időtartama pedig olyan változó, amely könnyedén mérhető. Emellett az emberi fejlődés során néhány vonás már nagyon korán megmutatkozik. Ezek nem morális alapúak, de közel állnak hozzá. Ilyen például, hogy a babák is átérzik mások fájdalmát (ez tükröződik az arcukon), és amint képesek erre fizikailag, megpróbálják a másikat megnyugtatni azzal, hogy megérintik vagy megsimogatják. Egy kísérletben a már járni tudó kicsik, ha látták, hogy egy felnőtt nem tud valamit egyedül megcsinálni, akkor spontán módon a segítségére siettek, bármiféle kérés, bátorítás vagy jutalom nélkül (Bloom, 2010).

Bloom (2010) több kísérletről is beszámol, amelyekben vagy rövid animációs filmet, vagy valódi figurákkal eljátszott jeleneteket mutattak a kicsiknek. Az egyik ilyen kísérletben azt vizsgálták, hogy mit gondolnak a segítségnyújtásról és a másik akadályozásáról. Az egyik jelenetben egyszerü geometriai formákat használtak, amelyeknek arcuk is volt. Egy piros labda fel szeretett volna gurulni egy dombra. Az egyik kisfilmben a sárga négyzet segíteni akart neki ebben, míg a másik filmben a zöld háromszög akadályozta őt azzal, hogy 
elé állt, és lelökte. Minden 9-12 hónapos baba hosszabb ideig figyelte azt a jelenetet, amelyikben a segítségnyújtásra látott példát. Ezt a kísérletet megismételték valódi, kézzel fogható figurákkal is, és azt találták, hogy a babák már 6-10 hónapos korban előnyben részesítették a segítő szereplőt a hátráltató szereplőhöz képest.

A gyerekek morális ítéletalkotása a mindennapi élményeiken keresztül formálódik: az emberek jutalmazásain és bántásain, valamint az igazságos és igazságtalan bánásmódon keresztül. A négy éves gyerekek már felismerik a saját szerepüket abban, ha valakit megbántottak, és annak a szükségességét, hogy ezt valahogy megpróbálják helyrehozni. Egy serdülő pedig már olyan komplex módon szemlél egy hasonló szituációt, hogy képes egyszerre reflektálni a másikkal való kapcsolatára, hogy abban hogyan viselkedett, és hogyan kellene viselkednie a jövőben (Turiel \& Banas, 2020).

A következőkben olyan szerzőket mutatok be, akik elfogadták Kohlberg elméletének alapvetéseit. Az általuk megalkotott vizsgálati eszközök közös jellemzője, hogy az erkölcsi fejlődés kohlbergi szakaszolását veszik alapul, és morális dilemmák megítélésén keresztül térképezik fel a válaszadó erkölcsi ítéletalkotását.

Damon és Rest (1978, idézi Vajda, 1999) olyan kutatók, akik elfogadták Piaget és Kohlberg klasszikus megközelítését. Munkásságuk során alátámasztják, hogy szakaszosság figyelhető meg az erkölcsi fejlődés során. Damon (1975, 1977, 1980, idézi Cole \& Cole, 2003) a javak és jutalmak elosztására vonatkozó gyermeki elképzeléseket vizsgálta. Kezdetben az Egyesült Államokban végzett vizsgálatokat, később azonban Izraelben, Puerto Ricoban és néhány európai országban is hasonló, szakaszos fejlődési mintát igazolt. Rest (1978, id. Vajda, 1999) eredményei szintén alátámasztják, hogy az erkölcsi ítéletek alakulását befolyásolja az életkor növekedése, és emellett arra jutott, hogy az iskolai végzettség szintén jelentős tényező.

James Rest (1979, idézi Enden et al., 2019) eredeti kérdőíve, a DIT-1 (Defining Issues Test) hat morális dilemmát tartalmaz, és 14 éves kortól alkalmazható. Az egyik történet a Kohlbergtől átvett híres Heinz-dilemma, de megtalálható benne az orvos dilemmája is, amely a következőképpen hangzik. Ha a végstádiumban lévő, haldokló beteg arra kéri az orvost, hogy adjon neki annyi gyógyszert, amivel segít neki meghalni, akkor ezt megteheti-e? A DIT kidolgozása során reagáltak Gilligan kritikájára, és különös hangsúlyt fektettek arra, hogy az eszköz nők és férfiak esetében egyaránt érvényes legyen (Rest, 1999). A DIT-1 után 20 évvel megszületett a DIT-2 (Rest et al., 1999, idézi Enden et al., 2019), amely eggyel kevesebb, azaz öt dilemmát tartalmaz. Úgy találták, hogy az első verzió nyelvezete és történetei kezdenek túlhaladottá válni, ezért frissítették a kérdőív anyagát.

A Georg Lind (2016) által kidolgozott MJT (Moral Judgment Test) egy kérdőív két morális dilemmával, melyet tízéves kor fölött és jó olvasási készség mellett alkalmazható. Az egyik dilemma a lopáshoz kapcsolódik, a másik az eutanázia kérdését feszegeti, és egyértelmü a hasonlóság az orvos dilemmájával, amely a DIT-1-ben jelent meg. A Lind-féle történet így hangzik: egy 
nő rákban haldoklott, és semmi remény nem volt a gyógyulásra. Szörnyü fájdalmai voltak, és annyira levolt gyengülve, hogy egy nagy adag fájdalomcsillapító a halálát okozhatta volna. Amikor már haldoklott, azért könyörgött az orvosának, hogy adjon neki annyi morfiumot, amennyi elég ahhoz, hogy megölje őt. Azt mondta, hogy nem tudja elviselni a fájdalmat, és néhány héten belül amúgy is meghalna. Az orvos eleget tett a kívánságának. A dilemma megismerése után a válaszadónak döntenie kell, hogy szerinte az adott cselekedet helyes vagy helytelen volt. Majd hat-hat érvet olvashat, amelyek a cselekedet mellett és ellen szólnak. Ezek elfogadhatóságát kilencfokú Likert-skálán kell megítélnie. Az érvek megfeleltethetők valamelyik kohlbergi szakasznak, s ez adja a besorolás alapját.

Yang és Wu (2008) kínai tinédzserek és fiatal felnőttek morális ítéletalkotását vizsgálták a Lind (2016) által fejlesztett MJT segítségével. A mintába összesen 724 fő került, életkorukat tekintve 14 és 27 év közöttiek. A morális ítéletalkotás tekintetében jelentős különbséget csak az elsőéves egyetemisták és az annál magasabb évfolyamon tanulók között találtak. Ez az eredmény különbözik a nyugati országokban végzett korábbi kutatások eredményétől. Ennek az lehet az oka, hogy a kínai oktatási rendszerben rendkívül hangsúlyos a matematika, a természettudományok, a humán és egyéb interdiszciplináris ismeretek elsajátítása, de a diákoknak kevés lehetőségük nyílik morális problémákkal találkozni, és az ezekről való vitában rutint szerezni. A szerzők lefordították Lind (2016) dilemmáit kínaira, és a kutatást megelőzően gondot fordítottak az eszköz validálására. A dilemmák kínai közegre való adaptálása azonban elmaradt, a szerzők jelzik is ezt a hiányosságot, mint a kutatás egyik korlátját. Kiemelik még, hogy a vizsgált diákok jóval toleránsabbak voltak az eutanáziával kapcsolatban, mint a lopással. Meglátásuk szerint ennek egyik lehetséges oka, hogy Kínában az eutanázia nem esik olyan egyértelmű szabályozás alá, mint a nyugati országokban. Ez a vizsgálat pont azért rendkívül jelentős, mert a várttal ellentétes eredményeket hozott. Egy nyugati, individualista beállítottságú kultúrkörben kidolgozott eszközt használtak fel Kínában, egy olyan kulturális közegben, ami híresen kollektivista beállítottságú. Ez rávilágít arra, hogy mekkora jelentősége van annak, ha egy eszköz más kulturális közegben született, mint amiben használni szeretnénk - s ezzel igazolódni látszik Turiel (Turiel \& Banas, 2020) álláspontja, mely szerint $a$ morális értékek megítélést jelentősen befolyásolja a kulturális kontextus.

Az MJT-hez hasonló felépítésü MDII (Moral Development Interview Invetiory) tíz morális dilemmát tartalmaz, és a kidolgozásakor gondot fordítottak arra, hogy a történetek illeszkedjenek a pakisztáni kultúrához. Négyéves kortól egészen felnőttkorig alkalmazható. Az eszköz alkalmazása során megfigyelhető volt a szakaszosság a morális fejlődésben (Khanam \& Iqbal, 2018). Safder és Abid (2018) az MDII-t használták egy olyan, nagy elemszámú kutatásban, amelyben összesen 1239 pandzsábi középiskolás diák került a vizsgált mintába. Szignifikáns összefüggést mutattak ki a tanárok morális viselkedése és a diákok erkölcsi fejlődése között. Ez az eredmény tulajdon- 
képpen egybevág azzal a korábbi kutatási eredménnyel, amelyre a szerzők utalnak is. Hart és Carlo (2005, idézi Safder \& Abid, 2018) hangsúlyozzák, hogy a gyerekek morális nevelésének legfontosabb meghatározói a szülők mellett a tanárok. Ez az eredmény rámutat arra, hogy az iskolai oktatás-nevelés során a pedagógusoknak a lexikális tudás átadása mellett lehetőségük van a gyerekek morális fejlődését célzottan támogatni.

\section{Egy fejlesztési megközelítés}

\section{- az erkölcsi ítéletalkotás mint a szociális kompetencia része}

A szociális kompetencia egyik jelentős hazai kutatója Nagy József (1996), aki rámutat arra, hogy az emberek, közösségek között mindig szociális kölcsönhatás van, amely a szociális viselkedésben nyilvánul meg. A szociális kölcsönhatást befolyásolja az aktuális szociális helyzet, a résztvevők szociális értékrendje és szociális kompetenciája. A szociális kompetencia olyan pszichikus rendszer, amely lehetővé teszi a szociális viselkedést, komponensei öröklöttek és tanultak. A szociális kompetencia fejlődésének feltétele ennek a komponenskészletnek a gyarapodása, ami a spontán és szándékos szocializációtól, a neveléstől függ. A szociális komponenskészlet elemei közé tartoznak: a szociális szokások, minták, készségek és ismeretek.

A szociális kompetencia fejlődése az öröklött és tanult tényezők hierarchizálódásával és a proszocialitás erősödésével jellemezhető. A proszocialitás az, ami lehetővé teszi, hogy viselkedésünk során mások érdekeit is figyelembe vegyük (Nagy, 1996). A szociális kompetencia fejlődését a család mellett az intézményes nevelés is jelentősen befolyásolja. Ha a család oldalát nézzük, akkor a pozitív szülő-gyermek viszony, a szülők szociális-érzelmi kompetenciája és gazdag szociális kapcsolatrendszere, a pozitív modellnyújtás és az elfogadó attitüd támogatják leginkább a fejlődést. Az óvoda és az iskola oldaláról meghatározó az intézmény fizikai környezete, szociális strukturáltsága és kultúrája (Tunstal, 1994, idézi Zsolnai \& Kasik, 2007). Nagy (1996) kiemeli az intézmény által közvetített szociális értékek jelentőségét. A pedagógus visszajelzései, empátiája, hitelessége és vezetési stílusa szintén fontos tényezők (Zsolnai, 1999). Azokban a csoportokban és osztályokban, ahol a pedagógusnak pozitív az önértékelése, segítőkész, következetes és megfelelően kezeli az érzelmeit, ott a kortársak között szignifikánsan több a pozitív interakció (Zsolnai \& Kasik, 2007).

A szociális kompetencia jelentös része tanult rendszer, amiből az következik, hogy tanítható is (Nagy \& Zsolnai, 2001). Ha az erkölcsi ítéletalkotást a szociális kompetencia részének tekintjük, azzal számos kézzel fogható eszközt nyerhetünk a gyakorlati pedagógia számára. Ezt a nézőpontot támogatja, hogy az itthon széles körben alkalmazott DIFER-ben (diagnosztikus fejlődésvizsgáló rendszer 4-8 évesek számára) az erkölcsi érzék vizsgálata a szocialitás vizsgálatának részeként jelenik meg. A vizsgálatvezető öt hétköznapi történetet mond, majd beszélgetést kezdeményez a gyerekkel. A törté- 
netek lopásról, együttérzésről, erőszakról, károkozásról és együttműködésről szólnak (Fazekasné et al., 2016). A szociális kompetencia fejlesztésére intézményes keretek között bevált technikát jelent a modellnyújtás, a felmerülő konfliktusok problémamegoldó kezelése, az elvárt viselkedés megerősítése, a szerepjátékok alkalmazása vagy történetek megbeszélése. Az eredményes fejlesztés feltétele, hogy a megfelelő módszerek és eszközök ismeretén túl a pedagógus maga is fejlett szociális kompetenciával rendelkezzen (Nagy \& Zsolnai, 2001). Ezek olyan technikák, amelyek alkalmasak lehetnek az erkölcsi ítéletalkotás fejlődésének támogatására is.

A szociális kompetencia első hazai kutatásai a '90-es évekre tehetőek. Ezekből, illetve a további DIFER-mérésekből az derült ki, hogy a szociális készségek fejlődésének jelentős része óvodáskorban, illetve azt megelőzően zajlik. Ez alól éppen az erkölcsi érzék jelent kivételt, mivel ennek a fejlettségi szintjében kifejezetten iskolába lépéskor, illetve az első osztályban láthatunk nagyobb ugrást. A pedagógiai tervezés szempontjából nem elhanyagolható tényező az sem, hogy az iskolába lépő gyerekek szocialitása szélsőségesen különböző fejlettségi szinteket mutat (Nagy, 2002, idézi Zsolnai, Kinyó \& Jámbori, 2012), illetve a szociális készségek 10 és 13 éves kor között spontán módon nem fejlődnek, és a gyerekek jelentős részénél 13 éves korban még tart a fejlődés. Ezért hát kiemelten fontos mind az óvodai, mind az iskolai fejlesztés (Józsa \& Zsolnai, idézi Zsolnai, Kinyó \& Jámbori, 2012). Ennek fényében a következőkben arról adok áttekintést, hogy hazai színtéren milyen lehetőségek vannak az erkölcsi ítéletalkotás fejlesztésére intézményes keretek között.

\section{Fejlesztési lehetőségek intézményes keretek között - hazai szabályozás, pedagógusképzés, módszertan}

Heller Ágnes (1994) szerint erkölcsöt tanítani annyit jelent, mint tartalmat adni annak a képességünknek, amellyel a jót és a rosszat megkülönböztetjük. Kamarás István (2013) szerint régen nem kérdés már, hogy tanítható-e az erkölcs, és az sem, hogy mikortól - az igazi kérdés sokkal inkább ez: hogyan, milyen módszertannal. Erre a kérdésre még visszatérünk. Először tekintsük át, milyen formában jelenik meg az erkölcsi nevelés a hazai intézményrendszerben.

A bölcsődei nevelés-gondozás országos alapprogramjában (2017) nem jelenik meg explicit módon az erkölcsi nevelés, ám az érzelmi és társas kompetenciák fejlesztése ott van a bölcsődei nevelés feladatai között. A mindennapi együttlét helyzetei a tolerancia és az empátia gyakorlásának színterei. A mesélés már ebben az életkorban is a személyiség formálásának kiváló eszköze.

Az óvodai nevelés feladatai között már ott van az erkölcsi nevelés, az erkölcsi tulajdonságok megalapozása, mint például az együttérzés, segítőkészség, önzetlenség és figyelmesség. Az óvodai életben jelentős tevékenységforma a verselés és mesélés. A mese, amit az óvodapedagógus kiegészíthet 
a bábozás és a dramatizálás eszközeivel, az óvodai erkölcsi fejlesztés egyik fö eszköze. Emellett a mindennapi nevelés részeként is megjelenik, indirekt formában az utánzás, modellkövetés és azonosulás révén (2012, Alapprogram).

Az Óvodai nevelés országos alapprogramjában és a Nemzeti alaptantervben meghatározott célok és fejlesztési területek a sajátos nevelési igényü gyermekek esetében is érvényesek ${ }^{2}$.

A bölcsőde és óvoda után tekintsük át az általános és a középiskola helyzetét. Kamarás István (2013) egyértelmủen amellett érvel, hogy az erkölcsi nevelés fontos színtere az iskola, és hasznos, ha önálló tantárgy és időkeret áll a pedagógus rendelkezésére. Ez teremti meg a lehetőséget sajátos arculatok megvalósítására - mert ennek a tantárgynak sokféle jól müködő alternatívája lehet.

Európában az erkölcstan jellegű tantárgyak helyzetét nagymértékben befolyásolja, hogy az adott országban mennyire erős a vallásos nevelés pozíciója. A kép szinte évről évre változik, de a hittan tantárgy alternatívái között a leggyakrabban az etika, , a világnézetileg semleges vallásismeret vagy vallástan, illetve a társadalomismeret vagy polgári ismeretek szerepelnek. A hazai jellemzőket megvizsgálva az látjuk, hogy a tantárgyi oktatás az ember-és erkölcstan megjelenésével kezdődött. Ez a születésekor, az 1990-es évek elején Európában kuriózumnak számított egyrészt azáltal, hogy komplex módon összehangolta a leíró és normatív embertudományokat, másrészt kötelező jellegével. Ebben az időszakban ugyanis a környező országokban sokkal jellemzőbb volt a hittan uralkodó helyzete. Aztán ez a tendencia megfordult a kétezres évekre: míg körülöttünk erősödött az oktatásügyben az ember-, erkölcs- és társadalomismereti tantárgyak jelenléte, addig hazánkban 2001 és 2010 között jelentősen gyengült. Ez legélesebben abban mutatkozott meg, hogy ebben az időszakban a tantárgy óraszáma a korábbihoz képest egyharmadára csökkent (Kamarás, 2013).

A 2012-es Nemzeti alaptantervben aztán az erkölcsi nevelés, mint kiemelt fejlesztési terület jelent meg. A tantárgyi keret mellett minden müveltségterületben részt kapott kisebb-nagyobb mértékben (2012, Nat). A 2012-es kerettanterv 1-8. évfolyam között heti egy órára növelte az óraszámot, és a tantárgy nevét erkölcstanra változtatta, míg a 9-12. évfolyamon meghagyta az alacsony óraszámot - a 11. évfolyamon heti egy órát -, és a tárgy nevét etikára módosította. Az erkölcstan kerettanterv deklarálja, hogy a pedagógusnak nem feladata erkölcsi kinyilatkoztatásokat megfogalmazni, ellenben a kérdezés, gondolkodás, állásfoglalás bátorítása, valamint a szabad beszélgetések, viták és a nézőpontváltást elősegítő szerepjátékok moderálása kifejezetten megjelenik benne. A tanulókra nem közlések befogadóiként, ha-

2 32/2012. (X. 8.) EMMI rendelet a Sajátos nevelési igényű gyermekek óvodai nevelésének irányelve és a Sajátos nevelési igényű tanulók iskolai oktatásának irányelve kiadásáról. 
nem mint aktív résztvevőkre tekint ${ }^{3}$. A tantárgy 2012-től kezdve az általános iskolában választható lett: a szülők dönthetnek arról, hogy a gyermekük erkölcstan vagy hit-és erkölcstan oktatásban részesüljön. Ez az elsőre demokratikusnak tünő lehetőség azt a veszélyt rejti magában, hogy mindkét csoport hátrányt fog szenvedni, mert bizonyos tartalmakkal értelemszerüen nem fog találkozni (Kamarás, 2013). Az erkölcstan tartalmát és követelményeit a valamit Nat szabályozza, a hit- és erkölcstan esetében az adott egyház nevében eljáró egyházi jogi személy dönt a keretekről (2011. év CXC. törvény a nemzeti köznevelésről). Sajnálatos, hogy a két tárgy céljainak, tartalmainak és követelményeinek egyeztetése azóta sem történt meg. Szükséges lenne, hogy a jelenleginél hatékonyabb párbeszéd folyjon a két tantárgy fejlesztői és pedagógusai között (Alexandrov, Fenyődi \& Jakab, 2015).

A NAT 2020-as módosításakor az általános iskola 1-8. évfolyamán megmaradt a heti egy óra, a 9-12. évfolyam palettájáról azonban teljes egészében lekerült az etika mint tantárgy. Az továbbra is választható, hogy a tanuló hités erkölcstan- vagy etikaoktatásban részesüljön. Láthatjuk, hogy a korábbi erkölcstan elnevezést etikára módosították ${ }^{4}$. A NAT 2020-as módosításához illeszkedő etika kerettantervben is fontos szempontként jelenik meg, hogy a tanító legyen nyitott, támogassa és tartsa tiszteletben az őszinte véleménynyilvánítást.

Milyen a szakemberképzés? A felvi.hu-n a 2020 szeptemberében induló képzéseket áttekintve azt láthatjuk, hogy a felsőoktatási paletta elég széles. Osztatlan tanári képzésben 10 félév alatt lehet etikatanári képesítést szerezni, de van etikatanári mesterképzés is. Ez utóbbi végzettséggel kifejezetten a középiskolai etika oktatásban lett volna lehetőség elhelyezkedni, de időközben ${ }^{5}$ a 9-12. évfolyamon megszüntették a tantárgy oktatását. Szakirányú továbbképzés elvégzése útján kettő félév alatt a jelentkezőből erkölcstan, etika szakos pedagógus válhat, valamint 4 félév után pedagógus szakvizsgát lehet tenni az etika és erkölcsi nevelés területén. A már gyakorlatban dolgozó pedagógusok számára hirdetett, akkreditált, 60 órás továbbképzés is elérhető, melynek keretében elsajátíthatóak az etika oktatásához szükséges elméleti és módszertani ismeretek. A tanfolyam kifejezetten az általános iskola felső tagozatára koncentrál. Az érdeklődő jelenléti és távoktatásos munkarenddel is találkozhat a továbbképzési lehetőségek böngészése közben.

Ki taníthatja a tantárgyat? A 2020-as NAT módosításához illeszkedő kerettanterv kimondja, hogy az etika tanítása empátiát, sokoldalú ismereteket, adaptivitást és rugalmasságot igényel. Olyan pedagógus vállalja az etika órák vezetését, aki szakmailag kompetens, megfelelő fejlődéslélektani, peda-

${ }^{3} 51 / 2012$. (XII. 21.) számú EMMI rendelet 1., 2. és 6. melléklete

${ }^{4}$ 5/2020. (I. 31.) Korm. rendelet a Nemzeti alaptanterv kiadásáról, bevezetéséről és alkalmazásáról szóló 110/2012. (VI. 4.) Korm. rendelet módosításáról

${ }^{5} 5 / 2020$. (I. 31.) Korm. rendelet a Nemzeti alaptanterv kiadásáról, bevezetéséről és alkalmazásáról szóló 110/2012. (VI. 4.) Korm. rendelet módosításáról 
gógiai, szakdidaktikai és módszertani felkészültséggel rendelkezik. Homor (2015) ajánlása szerint legyen tájékozott a modern nevelési és oktatási koncepciók területén, legyen jártas a kooperatív és interaktív pedagógiai módszerek használatában, valamint tapasztalt a konfliktuskezelésben. A jelenleg hatályos rendelet alapján ${ }^{6}$ az alsó tagozaton az osztályban egyébként is dolgozó tanító láthatja el a tárgy oktatását, felső tagozaton pedig rendelkezni kell a tárgynak megfelelő szakos tanári végzettséggel, vagy ennek hiányában az 5-8. évfolyamon pedagógus munkakör betöltésére jogosító végzettség mellett el kell végezni a fentebb már említett 60 órás továbbképzést. Azt látjuk tehát, hogy az elvárt magas szintű szakmai kompetenciák (és az elérhető felsőoktatási képzések sokszínűsége) ellenére ahhoz, hogy valaki etikát taníthasson, alsó tagozaton nem szükséges szakos tanári végzettség, felső tagozaton pedig opcionális.

Milyen módszertannal? A pedagógus feladatai közül a legfontosabb a gyermekközpontú szemlélet megvalósítása. El kell érnie, hogy a tanulók ne az ő véleményének akarjanak megfelelni, hanem lehessen vele vitatkozni. Tudatosítania kell, hogy nincs rossz válasz! Persze az lehetséges, hogy ő maga nem ért vele egyet. Az önismeret, önreflexió nemcsak a tanulók esetében kiemelkedő jelentőségű. A pedagógusnak magának is meg kell fogalmaznia, milyen értékeket és elveket tart fontosnak, és mit jelentenek ezek az ő számára. Fel kell készülnie arra is, hogy a gyerekek között lehetnek olyanok, akik az ő értékeit elutasítják (Fenyődi, 2015).

Az iskolai erkölcsi nevelés nem lehet sem represszív, sem diszkriminatív. Ezt az alapvető követelményt a pedagógus többféleképpen is megvalósíthatja, de a szakirodalomban leginkább elfogadott megoldás az értékartikulációs módszer. Ez ütközteti a már tisztázott álláspontokat, vitára bocsájtja őket, és nem kívánja meg, hogy a vita során „közös” értékítélet, vagy valamilyen kötelező jellegü értékrendszer fogalmazódjon meg a résztvevőkben (Mihály, 2001). Az értékartikulációs módszer megvalósítását a jelenleg hatályos köznevelési törvény is támogatja, legalábbis az állami és önkormányzati fenntartású intézményekben. A törvény kimondja, hogy a vallási és világnézeti információkat tárgyilagosan és sokoldalúan kell közvetíteni ${ }^{7}$.

Kamarás István (2013) a tanulót alkotótársnak tekinti, és olyan tevékenységeket ajánl, mint a mesehallgatás, filmnézés, olvasmányok feldolgozása és elemzése, és az ezekről való beszélgetés, könyvtári kutatás, sajtófigyelés, kiállítások rendezése, művészi alkotások létrehozása, kísérletezés. A felsorolásból kitetszik, hogy nagymértékben számít a tanulói aktivitásra és kreativitásra. Alexandrov, Fenyődi és Jakab (2015) kimondják, hogy pusztán a megértés nem vezet változáshoz. Erkölcsi kérdésekről tehát nem elég gondolkodni és beszélgetni, a gyerekek számára szituációkat kell teremteni,

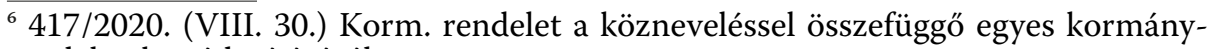
rendeletek módosításáról

${ }^{7}$ 2011. év CXC. törvény a nemzeti köznevelésről 
amelyben kipróbálhatják az újonnan megszerzett tudásukat. Ez ismét csak a tanulói aktivitás jelentőségét hangsúlyozza. Az óravezetésbe hatékonyan beépíthető a resztoratív szemlélet, az erőszakmentes kommunikáció és a drámapedagógia eszköztára.

Az erkölcsi érzék fejlesztésének egy gyakorlati módszere a Georg Lind által kifejlesztett erkölcsidilemma-diszkusszió modellje. A modellel kapcsolatos hazai tapasztalatokról Szekszárdi és Tusa (2006) számolnak be. Ez a módszer nem írja elő, hogy mi az erkölcsi szempontból helyes vagy helytelen döntés, hanem útmutatás mellett ugyan, de a döntés meghozását az egyénre bízza. A modell konkrét élethelyzetekkel dolgozik, amelyek esetében nincs egyértelműen jó vagy rossz megoldási alternatíva - éppen úgy, ahogyan ez az életben sem szokott egyértelmüen látszani. A különböző véleményekre építve vitára ösztönözhetjük a tanulókat. A vita mederben tartására kész séma áll rendelkezésre, mely 90 percre van tervezve, így két tanítási órát vesz igénybe. A tapasztalatok alapján erre a 90 percre addig van szükség, amíg az osztály begyakorolja a módszert, utána egy téma feldolgozására elegendő a 45 perces időkeret. Leginkább az 5-10. évfolyam között ajánlják. Bár kis mintán vizsgálták (egy veszprémi általános iskola felső tagozatán), a modell alkalmazásával kapcsolatos első hazai tapasztalatok egyértelműen pozitívak voltak. A diákokat akkor lehetett jól bevonni a vitába, ha a téma konkrét volt, és kapcsolódott a mindennapjaikhoz.

Az érdeklődő pedagógusok rendelkezésére áll számos módszertani ajánlás és segédlet, amelyekből ötleteket meríthetnek. Ilyen például az Erkölcstant tanitok $^{8}$ weboldal, amelyet Fenyődi Andrea, aki a 2012-es erkölcstan kerettanterv írója és tankönyvszerző, valamint Pénzesné Börzsei Anita szerkesztenek, aki szintén részt vett a tankönyvírásban. Az oldalt azzal a céllal hozták létre, hogy segítséget nyújtsanak az akkor, 2012-ben újonnan bevezetett tantárgy tanításához, illetve felületet teremtsenek a kollégáknak a gyakorlatban szerzett tapasztalatok megosztására. Az oldal rendkívül sokrétü tartalmat kínál: a módszertani és értékelési ajánlások mellett rengeteg tanári segédlet is található, úgymint a témában releváns, friss publikációk, játékgyüjtemények, szöveg- és versgyüjtemények, tematikus képgyüjtemény, módszertani segédkönyvek, óratervek. Az Oktatáskutató és Fejlesztő Intézet honlapján ${ }^{9}$ további, témák szerint rendszerezett képet, cikket és videót találhatunk, amelyekhez még a feldolgozást segítő kérdéseket és szempontokat is kidolgoztak.

\footnotetext{
${ }^{8}$ https://www.erkolcstant-tanitok.hu/

9 https://ofi.oh.gov.hu/gyujtemenyek?fbclid=IwAR09wecp53_cVvjI79YESoSn0OqGc6pfkNumLWJYuNiW5Qqgdh2sq5EZPs
} 


\section{Konklúzió}

Jelen munka célja, áttekinteni az erkölcsi ítéletalkotás fejlődésével és mérésével foglalkozó szakirodalmakat: a téma filozófiai gyökereinek megjelenésétől kezdve az olyan klasszikus elméletalkotókon keresztül, mint Jean Piaget és Lawrence Kohlberg, a napjainkban megjelenő új kutatási irányokig.

A két klasszikus kétségkívül jelentős hatással volt arra, amit az erkölcsi ítéletalkotás fejlődéséről gondolunk. Piaget (1965) és Kohlberg (1976) elméletein - vagy éppen ezek kritikáján - alapulnak azok a vizsgálati eszközök, amelyek a 20. század második felében születtek, és a mai napig forgalomban vannak. A DIT (Rest, 1978), az MJT (Lind, 2016) és az MDII (Khanam, 2018) közös jellemzője, hogy a kohlbergi szakaszolást veszik alapul, és morális dilemmák megítélésén keresztül térképezik fel a válaszadó erkölcsi ítéletalkotását. Azok a tapasztalatok, amelyek akkor keletkeztek, amikor ezeket az eszközöket más kulturális közegben használták, mint amiben a kidolgozásukra sor került (Yang \& Wu, 2008), rávilágítanak a kulturális hatások és a társadalmi kontextus jelentőségére az erkölcsi ítéletalkotásban (Turiel \& Banas, 2020). Az új eszközök mellett bemutattunk olyan kutatási irányokat, amelyek kiterjesztették a vizsgált populáció életkori határát a korai időszakra is, és az eredményeikkel felülírták azt, amit a morális gondolkodás kezdetéről sokáig gondoltunk (Bloom, 2010).

A másik, sokkal inkább a mindennapi pedagógiai gyakorlathoz kapcsolódó kérdéskör, amelyre választ kerestünk, hogy melyek azok az eszközök és módszerek, amelyekkel az erkölcsi ítéletalkotás fejlődését hatékonyan megtámogathatjuk, és a pedagógusoknak milyen lehetőségeik vannak a fejlesztésre intézményes keretek között. Először bemutattunk egy olyan megközelítést, amely az erkölcsi érzéket a szociális kompetenciába ágyazottan kezeli. Ennek a nézőpontnak hazánkban nagy hagyománya van a széles körben alkalmazott DIFER-mérések miatt. Ezután áttekintettük a hazai intézményi szabályozást a bölcsődei, óvodai, iskolai és középiskolai színtéren, és ennek közelmúltbeli változásait. Iskolai keretek között az erkölcstan/etika tantárgynak több évtizedes hagyománya van, mely a szakemberképzés sokszínűségében is megmutatkozik. Ezzel együtt, s az elvárt magas szintű szakmai kompetenciák ellenére jelenleg opcionális, és nem elvárás a szakos tanári végzettség. Ugyanakkor az érdeklődő pedagógusok rendelkezésére áll számos módszertani ajánlás és segédlet, amelyekből ötleteket meríthetnek, ezzel megalapozva a színvonalas szakmai munkát.

\section{Irodalom}

Alexandrov A., Fenyődi A. \& Jakab Gy. (2015). Az erkölcstan tantárgy útkeresése. Iskolakultúra, 25(9). 56-74.

https://doi.org/10.17543/ISKKULT.2015.9.56

Arisztotelész (1987). Nikomakhoszi etika. Budapest: Európa Könyvkiadó. 
Bandura, A. (1986). Social Foundations of Tought and Action: A Social Cognitive Theory. Prentice-Hall.

Bertók R. (2013). Az írásbeliség szigorú etikája és egy tipikus szándék-etika. In Bertók R. (Ed.), Bevezetés az etika történetének tanulmányozásába. (pp. 48-50). Virágmandula Kft.

Bloom, P. (2010). The Moral Life of Babies. The New York Times, https://www. nytimes.com/2010/05/09/magazine/09babies-t.html (2020. 18. 18.)

Cole, M., Cole, S. (2003). Fejlödéslélektan. Osiris Kiadó.

Enden, T., Boom, J., Brugman, D., \& Thoma S. (2019). Stages of moral judgment development: Applying item response theory to Defining Issues Test data. Journal of Moral Education, 48(4), 423-438.

https://doi.org/10.1080/03057240.2018.1540973

Fazekasné Fenyvesi M., Józsa K., Nagy J. \& Vidákovich T. (2016). Diagnosztikus Fejlödésvizsgáló rendszer 4-8 évesek számára. Mozaik Kiadó.

Fenyődi A. (2015). Az elme erkölcse. In Térátlépések konferenciakötet (pp. 97-104). Pannon Egyetem.

Freud, S. (1991). Az ősvalami és az én. Hatágú Síp Alapítvány.

Heller Á. (1994). Általános etika. Cserépfalvi Könyvkiadó.

Homor T. (2015). Korszerüség az erkölcstan/etika tanításban. Iskolakultúra, 25(10). 127-138.

Kamarás I. (2013). Tanítható-e az erkölcs? Neveléstudomány, 1(4). 6-20.

Kant, I. (1991). Az erkölcsök metafizikájának alapvetése. Gondolat Kiadó.

Khanam, A. \& Iqbal, M. Z. (2018). Development of MDII (Moral Development Interview Invetiory). Journal of Elementary Education, 22(2). 1-12.

Kohlberg, L. (1976). Moral stages and moralisation: The cognitive-developmnetal approach. In Lickona, J. (Ed.) Moral development behavior: Theory, research and social issues. (pp. 31-53), Holt, Reinhardt and Winston.

Lind, G. (2016). How to teach morality. Promoting deliberation and discussion, Reducing violence and deceit. Logos.

Mérei F., \& Binét Á. (1981). Gyermeklélektan. Gondolat Kiadó.

Mihály O. (2011). Pedagógiai, etikai, tudományos és jogi normák az iskolai erkölcsi szocializációban. Új Pedagógiai Szemle, 51(1) 4-16.

Mönks, F. \& Knoers, A. (2004). Fejlödéslélektan. Urbis Könyvkiadó.

Nagy J. (1996). Nevelési kézikönyv személyiségfejlesztő pedagógiai programok készitéséhez. Mozaik Oktatási Stúdió.

Nagy J. \& Zsolnai A. (2001). Szociális kompetencia és nevelés. In Báthory Z. \& Falus I. (Eds.), Tanulmányok a neveléstudomány köréből. (pp. 251-269). Osiris Kiadó.

Piaget, J. (1965). The Moral Judgement of the Child. Free Press. 
Piaget, J. (1969). A gyermek kétféle erkölcse. In Kiss Á. (Ed.), Válogatotttanulmányok. (pp. 407-439). Gondolat Kiadó.

Piaget, J. \& Inhelder, B. (2004). Gyermeklélektan. Osiris Kiadó.

Ranschburg J. (1998). Szeretet, erkölcs, autonómia. Okker Kiadó Kft.

Rousseau, J.-J. (1997). Emil, avagy a nevelésről. Papirusz Book.

Rest, J., Narvaez, D., Bebeau, M.J. \& Thoma, S.J. (1999). A Neo-Kohlbergian Approach: The DIT and Schema Theory. Educational Psychology Review, 11(4), 291-324.

https://doi.org/10.1023/A:1022053215271

Safder, M. \& Ch. Abid, H. (2018). Relationship between Moral Atmosphere of School and Moral Development of Secondary School Students. Bulletin of Education and Research, 40(3), 63-71.

Szekszárdi J., Horváth H. A., Buda M. \& Simonfalvi I. (2000). Serdülők erkölcsi szocializációja. (Útkeresés a labirintusban). Magyar Pedagógia, 100(4). 473-498.

Szekszárdi J. \& Tusa C. (2006). Osztályviták erkölcsi dilemmákról egy veszprémi általános iskolában. Új Pedagógiai Szemle, 56(7-8), 85-95.

Turiel, E. \& Banas, K. A. (2020). The Development of Moral and Social Judgements: Social Contexts and Process of Coordination. Eurasian Journal of Educational Research, 85. 23-44.

https://doi.org/10.14689/ejer.2020.85.2

Vajda Zs. (1999). Az erkölcsi ítélet fejlődésének kutatása Piaget és Kohlberg után. Magyar Pszichológiai Szemle, 54(3), 339-356.

Yang, S. G. \& Wu, H. H. (2008). The Features of Moral Judgement Competence among Chinese Adolescents. Asia Pacific Education Review, 9(3), 296-307. https://doi.org/10.1007/BF03026718

Zsolnai A. (1999). Összefüggések a szociális kompetencia egyes komponensei, a tanulási motívumok és az iskolai tudás között. JATEPress.

Zsolnai A. \& Kasik L. (2007). Az érzelmek szerepe a szociális kompetencia müködésében. Új Pedagógiai Szemle, 57(7-8), 3-16.

Zsolnai A., Kinyó L. \& Jámbori Sz. (2012). Szocializáció, szociális viselkedés, személyiségfejlődés. In Csapó B. (Ed.), Mérlegen a magyar iskola (pp. 327-366). Nemzeti Tankönyvkiadó.

\section{Törvények és rendeletek}

2011. évi CXC. törvény a nemzeti köznevelésről

https://net.jogtar.hu/jogszabaly?docid=a1100190.tv

2017. A Bölcsődei nevelés-gondozás országos alapprogramja

https://www.magyarbolcsodek.hu/files/shares/Bolcsodei\%20nevelesgondozas\%20orszagos\%20alapprogramja\%202017.pdf 
363/2012. (XII. 17.) Korm. rendelet az Óvodai nevelés országos alapprogramjáról https://net.jogtar.hu/jogszabaly?docid=a1200363.kor

110/2012. (VI. 4.) Korm. rendelet a Nemzeti alaptanterv kiadásáról, bevezetéséről és alkalmazásáról

https://net.jogtar.hu/jogszabaly?docid=a1200110.kor

51/2012. (XII. 21.) számú EMMI rendelet 1. melléklete https://kerettanterv.oh.gov.hu/01_melleklet_1-4/index_alt_isk_also.html

51/2012. (XII. 21.) számú EMMI rendelet 2. melléklete https://kerettanterv.oh.gov.hu/02_melleklet_5-8/index_alt_isk_felso.html

51/2012. (XII. 21.) számú EMMI rendelet 6. melléklete https://kerettanterv.oh.gov.hu/06_melleklet_9-12_szki/index_szakkozep.html

5/2020. (I. 31.) Korm. rendelet a Nemzeti alaptanterv kiadásáról, bevezetéséről és alkalmazásáról szóló 110/2012. (VI. 4.) Korm. rendelet módosításáról http://www.kozlonyok.hu/nkonline/MKPDF/hiteles/MK20017.pdf

A Nemzeti alaptanterv 2020-as módosításához illeszkedő tartalmi szabályozók (kerettantervek)

https://www.oktatas.hu/kozneveles/kerettantervek/2020_nat

417/2020. (VIII. 30.) Korm. rendelet a közneveléssel összefüggő egyes kormányrendeletek módosításáról

http://www.kozlonyok.hu/nkonline/MKPDF/hiteles/MK20196.pdf

32/2012. (X. 8.) EMMI rendelet a Sajátos nevelési igényü gyermekek óvodai nevelésének irányelve és a Sajátos nevelési igényü tanulók iskolai oktatásának irányelve kiadásáról

https://www.oktatas.hu/kozneveles/kerettantervek/2020_nat/iranyelvek_ alapprogramok 


\section{Vincze, Gy.}

\section{The development of moral judgement and how to support it in an institutional context}

This article offers a systematic review of the literature on the development and measurement of moral judgements. While there are numerous philosophical contributions to this topic, it is beyond the scope of this article to deal with all of them and we can present only the theories that influenced the twentieth century's major schools of psychology: psychoanalysis, social cognitive theory and cognitive development theory. Two classical theorists, Jean Piaget (1965) and Lawrence Kohlberg (1979), have significantly influenced contemporary thinking on the development of moral judgement. We present their theories and then outline some criticisms and recent research. This research offers some tools for analysing the level of moral judgement, and have significantly changed our thinking concerning the begining of moral thought in early childhood. We reflect on the integration of moral judgement into social competence, which is currently in favour in Hungary because of DIFER-measurements that are in wide use. We suggest ways to support the development of moral judgement in an institutional context, and discuss what kind of techniques and specialised forms of pedagogical training are available in Hungary.

Keywords: moral judgement, classical and contemporary theories, measurement, institutional regulation, methodology

Vincze Györgyi: https://orcid.org/0000-0002-9036-3184 